\title{
PERANAN MEDIA SOSIAL DALAM PENINGKATAN MOTIVASI BELAJAR PESERTA DIDIK PADA MATA PELAJARAN QUR'AN HADIS KELAS VIII MTS MADANI ALAUDDIN PAOPAO KABUPATEN GOWA
}

\author{
Abdul Jalil, ${ }^{1}$ Erwin Hafid ${ }^{2}$, Muhammad Amri ${ }^{3}$, Risna Mosiba ${ }^{4}$ \\ Universitas Islam Negeri Alauddin Makassar
}

\begin{abstract}
The role of social media for class VIII students in the Qur'an Hadith subject at MTs Madani Alauddin Pao-pao, Gowa Regency, is by utilizing social media WhatsApp and telegram as a communication instrument and study space, as well as utilizing YouTube social media as a learning instrument and learning resource. Students' learning motivation by using social media is summarized in: Students' learning motivation by using WhatsApp and telegram, students' learning motivation by using youtube and the factors that influence students' learning motivation. The role of whatsApp and telegram social media includes; Students are diligent in doing assignments and show tenacity in independent learning. The role of youtube social media, namely; increase the creativity of students and make students enjoy learning the Qur'an Hadith. The limitation of learning using social media is that learning with social media relies on signal strength.
\end{abstract}

Keywords: The role of social media, improvement, motivation to learn

\section{PENDAHULUAN}

Pendidikan bersifat mutlak dalam kehidupan, baik dalam kehidupan seseorang dan keluarga, maupun dalam kehidupan berbangsa dan bernegara, sehingga pendidikan sangat penting dan tidak dapat dipisahkan dengan kehidupan, karena kemajuan suatu bangsa dan negara banyak ditentukan oleh kemajuan pendidikan bangsa dan negara tersebut. Mengingat sangat pentingnya dalam kehidupan, sehingga pendidikan harus dilaksanakan sebaik-baiknya, agar memperoleh hasil sesuai dengan yang diharapkan. ${ }^{1}$

Menurut Undang-Undang Republik Indonesia Nomor 20 Tahun 2003 Tentang Sistem Pendidikan Nasional Pasal 1 "Pendidikan adalah usaha sadar dan terencana untuk mewujudkan suasana belajar dan proses pembelajaran agar peserta didik secara aktif mengembangkan potensi dirinya untuk memiliki kekuatan spiritual keagamaan, pengendalian diri, kepribadian, kecerdasaan, akhlak mulia, serta keterampilan yang diperlukan dirinya, masyarakat, bangsa dan negara".2

Dari pengertian pendidikan jelas bahwa pelaksanaan pendidikan itu pada umumnya adalah mengembangkan mutu dan potensi sumber daya manusia untuk membangun bangsa yang lebih maju. Adanya perkembangan ilmu pengetahuan dan teknologi akan

\footnotetext{
${ }^{1}$ Sudirman N, dkk, Ilmu Pendidikan (Cet. III; Bandung: Remadja Karya, 1989), h. 3.

${ }^{2}$ Badan Penelitian dan Pengembangan Depdiknas, Undang-Undang Sistem Pendidikan Nasional (Cet. 6; Jakarta: Sinar Grafika, 2014), h. 3.
} 
berpengaruh terhadap kualitas sistem pembelajaran di sekolah. Artinya dengan kehadiran media sosial, sekolah dituntut untuk lebih kreatif dalam mengelola pembelajaran menjadi menarik dan efektif, baik dalam proses pembelajaran maupun media pembelajaran sehingga peserta didik akan menjadi senang dan tidak merasa bosan selama proses pembelajaran berlangsung sehingga memperoleh hasil belajar yang maksimal.

Untuk mengembangkan potensi peserta didik, sangat diperlukan inovasi dalam pembelajaran sehingga dapat menarik perhatian peserta didik. Banyak hal yang dapat dilakukan untuk membuat peserta didik tertarik dalam mengikuti proses pembelajaran, misalnya dengan menggunakan media pembelajaran yang sesuai dengan materi pelajaran. Proses kegiatan pembelajaran akan berlangsung dengan baik jika ditunjang dengan media pembelajaran yang memadai serta tepat dalam penggunaannya.

Peran guru dalam pembelajaran adalah sebagai korektor, inspirator, informator, organisator, motivator, inisiator, fasilitator, pembimbing, demonstrator, pengelola kelas, mediator, supervisor, evaluator. ${ }^{3}$ Guru dalam menjalankan perannya pada proses pembelajaran membutuhkan alat bantu yang dapat menyampaikan informasi kepada peserta didik. Pemakaian media pembelajaran dalam proses pembelajaran dapat membangkitkan keinginan dan minat yang baru, membangkitkan motivasi dan rangsangan kegiatan belajar, dan bahkan membawa pengaruh-pengaruh psikologis terhadap siswa. ${ }^{4}$

Sesuai dengan perkembangan zaman dan perkembangan teknologi, dalam proses pembelajaran menuntut peserta didik untuk lebih aktif, maka media sosial dapat dijadikan salah satu media untuk membantu dalam proses pembelajaran. Banyak cara yang dapat dikembangkan dalam pembelajaran untuk melibatkan peserta didik aktif melalui stimulus media sosial. Berkenaan dengan era generasi 4.0 yang berarti bahwa pemanfaatan media/IT menjadi suatu keniscayaan, sumber belajar tidak dibatasi yang sifatnya konvensional, karena itu media menjadi salah satu sumber dan sarana pembelajaran, apalagi di masa covid sekarang.

Media sosial dapat membantu peserta didik dalam proses pembelajaran Qur'an Hadis, media ini memungkinkan siswa lebih aktif dalam mengikuti pembelajaran, selain itu peserta didik tidak merasa bosan dengan menampilkan bentuk gambar bergerak dan juga suara yang bervariasi. Dengan penggunaan media pembelajaran media sosial berupa gambar, gambar bergerak dan suara yang bervariasi, peserta didik bisa termotivasi dalam mengikuti proses pembelajaran.

Motivasi merupakan kekuatan yang mendorong seseorang melakukan sesuatu untuk mencapai tujuan, kekuatan ini dirangsang oleh adanya berbagai macam kebutuhan. ${ }^{5}$

${ }^{3}$ Syaiful Bahri Djamarah, Guru dan Anak Didik dalam Interaksi Edukatif: Suatu Pendekatan Teoritis Psikologis, Cet. 3, (Jakarta: Rineka Cipta, 2010), h. 43.

${ }^{4}$ Azhar Arsyad, Media Pembelajaran (Cet. 17; Jakarta: Rajawali Pers, 2014), h. 19.

${ }^{5}$ Nyayu Khodijah, Psikologi Pendidikan (Cet. 2; Jakarta: Raja Grafindo Persada, 2014), h. 150. 
Seseorang yang memiliki motivasi untuk melakukan sesuatu cenderung memberikan perhatian yang lebih besar kepada obyek tersebut. Namun jika obyek tersebut tidak menimbulkan rasa senang maka seseorang tidak akan memiliki motivasi terhadap obyek tersebut.

Motivasi merupakan faktor yang mempengaruhi keberhasilan dalam proses belajar. Jika seorang peserta didik memiliki motivasi belajar yang besar, maka peserta didik akan bersemangat mengikuti pelajaran hingga seorang peserta didik tersebut akan cepat mengerti dan mengingat materi yang dipelajarinya. Motivasi juga merupakan faktor utama yang menentukan keterlibatan peserta didik dalam belajar. Dalam proses pelaksanaan pembelajaran dapat diketahui bagaimana motivasi belajar peserta didik tersebut dengan cara mengamati langsung tingkah laku peserta didik tersebut.

\section{METODOLOGI PENELITIAN}

1. Pendekatan Pedagogik

Pendekatan ini mengarah pada perkembangan dan pertumbuhan rohani dan jasmani yang memerlukan bimbingan dan pengarahan melalui proses pendidikan. ${ }^{6}$ Pendekatan pedagogik ini dianggap sangat relevan dengan penelitian mengingat orientasi penelitian yang akan dilakukan adalah tentang pendidikan.

2. Pendekatan Psikologis

Pendekatan psikologi ini dimaksudkan untuk mengidentifikasi obyek penelitian, yakni unsur ruhani peserta didik. Unsur ruhani tersebut ialah motivasi peserta didik, bahwa perihal motivasi itu adalah sesuatu hal yang hanya dapat dideteksi dengan mempelajari kejiwaan peserta didik.

\section{TINJAUAN TEORETIS}

\section{A. Tinjauan Tentang Peranan Media Sosial dalam Pembelajaran Qur'an Hadis}

Media sosial merupakan perkembangan dari teknologi-teknologi web berbasis internet, memudahkan semua orang untuk berkomunikasi dan berpartisipasi. ${ }^{7}$ Megan Poore menegaskan bahwa Social media are simply those digital technologi that alow usersto easily create and share material with others via the internet. The internet hasntalways been used in this way. ${ }^{8}$ Artinya media sosial adalah teknologi digital yang

${ }^{6}$ M. Arifin, Ilmu Pendidikan Islậm Suatu Tinjauan Teoretis dan Praktis Berdasarkan Pendekatan Interdisipliner (Cet. V; Jakarta: BumiAksara, 2000), h. 136.

${ }^{7}$ Dan Zarella, The Social Media Marketing Book (Jakarta: PT Serambi Ilmu Semesta Anggota IKAPI : 2010), h. 2-3.

${ }^{8}$ Megan Poore, Studying and Researching with Social Media (Los Angeles: Sage Study Skills, 2014), h. 3 . 
memudahkan penggunanya untuk membuat dan berbagi materi dengan orang lain melalui internet. Internet selalu dibutuhkan oleh setiap orang.

Kehadiran media sosial (Facebook, Twitter, Youtube, Flickr, Path, Instagram, Blog, Skype, Snapchat, dan Messaging Apps seperti : WhatsApp, Line, Blackberry Messanger, Yahoo Messanger, Google Talk, dan lain sebagainya) adalah torehan sejarah yang telah membawa perubahan dalam proses komunikasi manusia. Proses komunikasi yang selama ini dilakukan hanya melalui komunikasi tatap muka, komunikasi kelompok, komunikasi massa, berubah total dengan perkembangan teknologi komunikasi virtual, khususnya internet. Perubahan itu bisa dilihat pada tempat umum dimana orang lebih asyik berkomunikasi dengan gadget yang mereka miliki daripada dengan orang-orang yang berada di dekatnya. ${ }^{9}$

Berbagai situs jejaring sosial memudahkan pengguna untuk berbagi ide, saran, pandangan, aktivitas, informasi, acara, ajakan dan ketertarikan di dalam jaringan individu masing-masing orang. Selain layanan jejaring sosial bersifat terpusat pada individu, sosok atau tokoh, berkembang pula layanan komunitas yang sifatnya lebih terpusat pada grup atau kelompok bersama. ${ }^{10}$

Perkembangan teknologi informasi yang sangat pesat dewasa ini, khususnya perkembangan teknologi internet turut mendorong berkembangnya konsep pembelajaran jarak jauh. Ciri teknologi internet yang selalu dapat diakses kapan saja, dimana saja, multiuser, serta menawarkan segala kemudahannya telah menjadikan internet suatu media yang sangat tepat bagi perkembangan pendidikan. ${ }^{11}$ Upaya pengembangan dan pemanfaatan internet juga selalu dilakukan di antaranya adalah implementasi e-learning. Dengan e-learning seorang pengajar dapat membuat sebuah pembelajaran yang interaktif. $^{12}$

Media sosial dalam proses proses pembelajaran memiliki peranan tersendiri. Guru mengambil peranan memulai pemanfaatan media sosial. Indikasinya tampak guru yang menganjurkan siswa untuk membuat grup WhatsApp. Salah seorang siswa menyatakan mereka lebih senang dan bersemangat jika belajar dengan menggunakan media sosial karena memperluas pengetahuan dan dapat merujuk berbagai sumber dan merasa lebih mudah mengingat informasi. Dia juga mengungkapkan bahwa lebih senang mengerjakan tugas dengan menggunakan media sosial, lebih senang berdiskusi dengan media sosial,

\footnotetext{
${ }^{9}$ Elvi Susanti “Glosarium Kosakata Bahasa Indonesia dalam Ragam Media Sosial” Universitas Islam Negeri Syarif Hidayatullah Jakarta, Dialektika Jurnal Bahasa, Sastra, dan Pendidikan Bahasa dan Sastra Indonesia 3 (2), 2016, h. 230.

${ }^{10}$ Tim Pusat Humas Kementerian Perdagangan RI, Panduan Optimalisasi Media Sosial untuk Kementerian Perdagangan RI (Jakarta: Pusat Hubungan Masyarakat, 2014), h. 23.

${ }^{11}$ Hamzah B. Uno, Model Pembelajaran Menciptakan Proses Belajar Mengajar yang Kreatif dan Efektif (Jakarta : Bumi Aksara, 2012), h. 21.

${ }^{12}$ A. Andrizal dkk. "Pengembangan Media Pembelajaran Interaktif Padasistem E-Learning" Universitas Negeri Padang.Invotek: Jurnal Inovasi Vokasional dan Teknologi, 17, 2 (2017), h. 1-10.
} 
lebih aktif menyampaikan pendapatnya melalui dunia maya dari pada menyampaikan pendapatnya di dunia nyata (diskusi dalam kelas). ${ }^{13}$

Berdasar pada observasi awal yang dilakukan oleh peneliti sebagaimana dipaparkan pada BAB I, media sosial yang menjadi fokus dalam penelitian ini adalah WhatsApp, Telegram dan Youtube. Media Sosial WhatsApp dan Telegram digunakan sebagai media komunikasi antar guru dan peserta didik, peserta didik dengan peserta didik, guru dengan guru dan guru dengan orangtua peserta didik, sedangkan media Sosial Youtube digunakan sebagai media searching tentang pembelajaran yang sedang diajarkan.

\section{B. Motivasi Belajar}

\section{a. Konsep Dasar Motivasi Belajar}

Wina Sanjaya mengatakan bahwa dalam proses pembelajaran, motivasi merupakan salah satu aspek dinamis yang sangat penting. Sering terjadi peserta didik yang kurang berprestasi bukan disebabkan oleh kemampuannya yang kurang, akan tetapi dikarenakan tidak adanya motivasi untuk belajar sehingga ia tidak berusaha untuk mengarahkan segala kemampuannya. Dalam proses pembelajaran tradisional yang menggunakan pendekatan ekspositori kadang-kadang unsur motivasi terlupakan oleh guru. Guru seakan-akan memaksakan peserta didik menerima materi yang disampaikannya. Keadaan ini tidak menguntungkan karena peserta didik tidak dapat belajar secara optimal yang tentunya pencapaian hasil belajar juga tidak optimal. Pandangan moderen tentang proses pembelajaran menempatkan motivasi sebagai salah satu aspek penting dalam membangkitkanmotivasi belajar peserta didik. Motivasi belajar merupakan sesuatu keadaan yang terdapat pada diri seseorang individu dimana ada suatu dorongan untuk melakukan sesuatu guna mencapai tujuan. ${ }^{14}$

Menurut Mc Donald sebagaimana dikutip Kompri bahwa motivasi adalah suatu perubahan energidi dalam pribadi seseorang yang ditandai dengan timbulnya afektif (perasaan) dan reaksi untuk mencapai tujuan. Dengan demikian munculnya motivasi ditandai dengan adanya perubahan energy dalam diri seseorang yang dapat disadari atau tidak. $^{15}$

Motivasi dipandang sebagai dorongan mental yang menggerakkan dan mengarahkan perilaku manusia, termasuk perilaku belajar. Dalam motivasi terkandung adanya keinginan yang mengaktifkan, menggerakkan, menyalurkan, dan mengarahkan

\footnotetext{
${ }^{13}$ Sholekah Dina Dahniary, Wahyuni Siti, pemanfaatan Media Sosial dalam Proses Pembelajaran di SMPN 1 Mojo Kediri (Indonesian Jurnal of Islamic Education, 2019) volume 2.

${ }^{14}$ Wina Sanjaya, Kurikulum dan pembelajaran, Teori dan praktek Pengembangan Kurikulum KTSP ( Jakarta: Kencana, 2010), h. 249.

${ }^{15}$ Kompri, Motivasi Pembelajaran Perspektif Guru dan Peserta didik, h. 229.
} 
sikap dan perilaku individu belajar. ${ }^{16}$ Motivasi belajar adalah seluruh daya penggerak di dalam diri peserta didik yang menimbulkan kegiatan belajar yang menjamin kelangsungan dari kegiatan belajar yang memberikan arah pada kegiatan belajar sehingga tujuan yang dikehendaki oleh subjek belajar itu dapat dicapai. ${ }^{17}$

Motivasi yang ada pada diri setiap orang itu memiliki ciri-ciri, sedikitnya menurut Dimyati yaitu sebagai berikut:

1) Tekun menghadapi tugas (dapaat bekerja terus-menerus dalam waktu yang lama, tidak pernah berhenti sebelum selesai).

2) Ulet menghadapi kesulitan (tidak lekas putus asa). Tidak memerlukan dorongan dari luar untuk berprestasi sebaik mungkin (tidak cepat puas dengan prestasi yang telah dicapainya).

3) Menunjukkan minat terhadap bermacam-macam masalah.

4) Lebih senang bekerja mandiri.

5) Cepat bosan pada tugas-tugas yang rutin.

6) Dapat mempertahankan pendapatnya.

7) Tidak mudah melepaskan hal yang diyakini itu.

8) Senang mencari dan memecahkan masalah soal-soal. ${ }^{18}$

b. Fungsi dan Manfaat Motivasi Belajar

Menurut Kompri Kedudukan motivasi dalam belajar tidak hanya memberikan arah kegiatan belajar secara benar, lebih dari itu dengan motivasi seseorang akan mendapat pertimbangan-pertimbangan positif dalam kegiatan belajar. Motivasi merupakan hal yangsangat penting sebagai berikut:

1) Motivasi memberikan semangat seorang pelajar dalam kegiatan belajarnya.

2) Motivasi memberi petunjuk pada tingkah laku. ${ }^{19}$

Kompri mengatakan bahwa dalam proses pembelajaran motivasi baik bagi guru dan peserta didik adalah sangat penting dalam mencapai keberhasilan belajar sesuai tujuan yang diharapkan. Adapun pentingnya motivasi bagi guru adalah sebagai berikut:

\footnotetext{
${ }^{16}$ Dimyati dkk., Belajar dan Pembelajaran (Jakarta: Rineka Cipta, 2009), h. 80.

${ }^{17}$ AM. Sardiman, Interaksi dan Motivasi Belajar Mengajar, h. 75.

${ }^{18}$ Dimyati dkk., Belajar dan Pembelajaran, h. 83.

${ }^{19}$ Kompri. Motivasi Pembelajaran Perspektif Guru dan Peserta didik, h. 233.
} 
1) Membangkitkan, meningkatkan dan memelihara semangat peserta didik untuk belajar sampai berhasil.

2) Mengetahui dan memahami keragaman motivasi di kelas.

3) Meningkatkan dan menyadarkan guru untuk memilih keragaman peran seperti sebagai penasehat, fasilitator, instruktur, teman diskusi atau pendidik.

4) Memberi peluang guru untuk unjuk kerja rekayasa pedagogis. ${ }^{20}$

Guru dapat mengarahkan peserta didik agar memahami pentingnya motivasi atau dorongan berkeinginan untuk belajar. Adapun manfaat motivasi belajar bagi peserta didik yaitu sebagai berikut:

1) Menyadarkan kedudukan pada awal belajar, proses, dan hasil akhir;

2) Menginformasikan tentang kekuatan usaha belajar, yang dibandingkan dengan teman sebaya;

3) Mengarahkan kegiatan belajar;

4) Membesarkan semangat belajar;

5) Membesarkan semangat belajar;

6) Menyadarkan tentang adanya perjalanan belajar dan kemudian bekerja (di selaselanya adalah istirahat atau bermain) yang bersinambungan. ${ }^{21}$

\section{Tinjauan Tentang Mata Pelajaran Qur'an hadis}

Pendidikan sebagai usaha membina dan mengembangkan pribadi manusia; aspek rohaniah, dan jasmaniah, juga harus berlangsung secara bertahap. Sebab tidak ada satupun makhluk ciptaan Allah yang secara langsung tercipta dengan sempurna tanpa melalui suatu proses. ${ }^{22}$ Maka dengsan itu Islam sangat menaruh perhatian terhadap pendidikan, khususnya proses pertumbuhan anak dari awal pemilihan tempat benih sampai membentuk pribadi individu dalam kehidupan. Dan yang turut berperan dalam pembinaan kepribadian dan pendidikan anak adalah orang tua, masyarakat dan sekolah. ${ }^{23}$

${ }^{20}$ Kompri. Motivasi Pembelajaran Perspektif Guru dan Peserta didik, h. 234.

${ }^{21}$ Dimyati dkk., Belajar dan Pembelajaran, h. 85.

${ }^{22}$ H. Muzayyin Arifin, Filsafat Pendidikan Islam, h. 12.

${ }^{23}$ Muhammad Abd. Alim, al-Tarbiyah wa al-Tanmiyah.. fi al-Islam (Riyadh: KSA, 1992), h. 4445. 
Muhaimin berpendapat bahwa pendidikan agama Islam bermakna upaya mendidikkan agama Islam atau ajaran Islam dan nilai-nilainya agar menjadi pandangan dan sikap hidup seseorang. Dari aktivitas mendidikkan agama Islam itu bertujuan untuk membantu seseorang atau sekelompok anak didik dalam menanamkan dan /atau menumbuh kembangkan ajaran Islam dan nilai-nilainya untuk dijadikan sebagai pandangan hidupnya. ${ }^{24}$

Ahmad D. Marimba; mengemukakan bahwa pendidikan Islam adalah bimbingan atau pimpinan secara sadar oleh pendidik terhadap perkembangan jasmani danrohani peserta didik menuju terbentuknya kepribadiannya yang utama (insan kamil). ${ }^{25}$ Juga Ahmad Tafsir; mendefinisikan pendidikan Islam adalah bimbingan yang diberikan oleh seseorang kepada seseorang agar ia berkembang secara maksimal sesuai dengan ajaran Islam. ${ }^{26}$

Dari definisi pendidikan agama Islam dan beberapa definisi pendidikan Islam di atas, terdapat kemiripan makna yaitu keduanya sama-sama mengandung arti pertama, adanya usaha dan proses penanaman sesuatu (pendidikan) secara continue. Kedua, adanya hubungan timbal balik antara orang pertama (orang dewasa, guru, pendidik) kepada orang kedua, yaitu peserta dan anak didik. dan ketiga adalah akhlakul karimah sebagai tujuan akhir. Namun tidak kalah pentingnya dari aspek epistemologi bahwa pembinaan dan pengoptimalan potensi; penanaman nilai-nilai Islam dalam jiwa, rasa, dan pikir; serta keserasian dan keseimbangan.

Inti dari pembahasan kurikulum di atas adalah mengenai pengetahuan yang didapat, penerapan dari pengetahuan tersebut dan aspek nilai. Semua aspek ini bila ditinjau dari pandangan pendidikan agama Islam saling mendukung dan tidak terdapat kontradiktif di mana kurikulum pendidikan nasional bertujuan menumbuhkan keimanan dan ketaqwaan terhadap Tuhan Yang Maha Esa, menumbuhkan penalaran yang baik (mau belajar, ingin tahu, kreatif dan bertanggung jawab). ${ }^{27}$

Demikian dengan mata pelajaran pendidikan agama Islam, di dalamnya terdapat muatan pembelejaran spesifikasi qur'an hadits. Mata pelajaran al-Qur'an dan hadis merupakan unsur mata pelajaran pendidikan agama islam (PAI) pada madrasah yang memberikan pendidikan kepada peserta didik untuk memahami dan mencintai al-Qur'an dan hadits sebagai sumber ajaran islam dan mengamalkan isikandungan dalam kehiduapan sehari-hari. ${ }^{28}$

\footnotetext{
${ }^{24}$ H. Muzayyin Arifin, Filsafat Pendidikan Islam, h. 7-8.

${ }^{25}$ Al-Rasyidin dan H. Samsul Nizar, Filsafat Pendidikan Islam, h. 32.

${ }^{26}$ Ahmad Tafsir, Ilmu Pendidikan dalam Perspektif Islam (Cet. II : Bandung: PT. Remaja Rosdakarya, 1994), h. 32.

${ }^{27}$ E. Mulyasa, Kurikulum Berbasis Kompetensi, Konsep, Karakteristik, dan Implementasi (Bandung: PT. Remaja Rosdakarya, 2004), h. 41-42.

${ }^{28}$ Akmal Hawi, Kompetensi Guru PAI (Palembang: IAIN Raden Fatah Pres), h. 145
} 
Pembelajaran al-Qur'an dan hadits bertujuan agar peserta didik gemar membaca Al-Qur'an dan hadits dengan benar, serta mempelajarinya, memahami, meyakini kebenarannya, dan mengamalkan ajaran-ajaran dan nilai-nilai yang terkandung di dalamnya sebagai petunjuk dan pedoman dalam seluruh aspek kehidupan. ${ }^{29}$

Berdasarkan penjelasan di atas, dapat dipahami bahwa al-Qur'an dan hadits merupakann muatan dalam pembelajaran pendidikan agama Islam dengan ciri khas yang menekankan pada kiat-kiat memahami subtansi al-Qur'an dan hadits itu sendiri baik dari sisi teks ataupun dari sisi kontekstual melalui ragam pendekatan. Ragam pendapat di atas sedikitnya menjadi bahan bagi penyusun sebagai bekal menuju lokasi penelitian sekaligus data pendukung yang berfungsi menguji kesesuain teori yang ada dengan proses pembelajaran yang diimplementasikan di MTs Madani Paopao Kabupaten Gowa.

\section{HASIL PENELITIAN DAN PEMBAHASAN}

\section{A. Peranan Media Sosial bagi Peserta Didik Kelas VIII MTs Madani Alauddin Paopao}

\section{Kabupaten gowa}

\section{Peranan Media Sosial WhatsApp dan Telegram}

a. Sebagai Instrumen Komunikasi

Melihat redaksi namanya "media sosial" tentunya dapat dengan mudah dipahami motif atau alasan utama media sosial diciptakan yakni sebagai media untuk memperkuat atau memperluas ruang hubungan sosial sehingga beberapa sekat yang semula menghalangi seseorang untuk saling sapa menyapa misalnya karena disebabkan oleh jarak atau kesehatan dan keadaan lain yang semisal maka dengan media sosial, sekatsekat yang menghalangi itu tidak lagi menjadi suatu halangan seseorang dalam berinteraksi.

Kembali pada hakikat media sosial, utamanya ia berfungsi untuk memudahkan hubungan sosial masyarakat dua arah atau masyarakat yang berlainan tempat, dengan demikian media sosial merupakan alat komunikasi untuk memberikan informasi atau materi dengan bantuan tenologi berbasis internet. Media sosial seringkali dimanfaatkan sebagai instrument untuk mempermudah aktivitas atau profesi. Kenyataan tersebut dapat diamati pada hampir setiap elemen perusahaan, instansi, lembaga pendidikan, bahkan individu bahwa saat ini media sosial bukan lagi menjadi sesuatu yang langka didapatkan. Media sosial menyediakan fasilitas komunikasi yang instan dan sederhana sehingga seseorang tidak membutuhkan waktu yang lama untuk dapat mengoperasikannya.

Maraknya pengguna media sosial sebagaimana dijelaskan sebelumnya juga memasuki ruang-ruang pendidikan mulai level sekolah hingga pada level perguruan tinggi khususnya sebagai alat yang memudahkan intensitas komunikasi antara elemen

${ }^{29}$ Akmal Hawi, Kompetensi Guru PAI, h. 145 
lembaga pendidikan baik guru dengan guru, guru dengan peserta didik, atau peserta didik dengan peserta didik lainnya.

Pentingnya media sosial sebagai instrument komunikasi khususnya dalam ruang pendidikan semakin jelas di era pandemi covid-19 dimana setiap orang diminta menjaga jarak, bekerja, dan belajar dari rumah. Kiranya tanpa teknologi dan media sosial maka setiap lini akan mengalami kepincangan berlarut-larut sampai pada pandemi covid-19 berlalu.

Media sosial dalam konteks instrument komunikasi antara guru dengan peserta didik khususnya pada mata pelajaran Qur'an Hadis dimanfaatkan dengan membuat group pada masing-masing kelas dan tingkatan sebagai media informasi meliputi jadwal proses pembelajaran. ${ }^{30}$ Hasil observasi tersebut senada dengan hasil wawancara sebagaimana dipaparkan oleh Ahmad selaku guru mata pelajaran Qur'an Hadis:

Media sosial yang digunakan sebagai alat komunikasi yaitu whatsapp dan telegram. Namun dalam prosesnya, kami lebih banyak menggunakan telegram, karena pada media sosial telegram terdapat vitur pengingat yang diatur sepuluh menit sebelum pembelajaran dimulai sehingga peserta didik dapat mampersiapkan diri untuk melaksanakan proses belajar mengajar mata pelajaran Qur'an Hadis. ${ }^{31}$

Group media sosial (termasuk group kelas) bukan lagi merupakan sesuatu yang asing di kalangan generasi millennial sekarang ini, umumnya group media sosial seperti whatsapp, line, telegram, dan aplikasi serupa lainnya umumnya cenderung dijadikan wadah silaturahim sekaligus alat bantu dalam mempermudah perencanaan sebelum memasuki proses pembelajaran meliputi waktu, materi pembahasan, atau kiat-kiat yang akan dilakukan selama proses pembelajaran berlangsung.

Bagi pendidik yang kreatif, group media sosial juga dapat dijadikan instrument komunikasi khususnya dalam memotivasi peserta didik di luar jam belajar. Di waktu senggang, pendidik dapat berinteraksi dengan peserta didik dengan memberikan stimulus agar peserta didik terdorong giat belajar misalnya dengan mengajak peserta didik agar group media sosial dapat dijadikan wadah diskusi.

Penjelasan di atas sesuai dengan hasil wawancara peneliti sebagaimana pernyataan Ahmad selaku guru Qur'an Hadis di Mts. Madani Alauddin Pao-pao:

Ada kalanya peserta didik bertanya melalui pesan pribadi kepada guru dan pertanyaan itu berulang-ulang ditanyakan oleh peserta didik yang lainnya. Sehingga untuk menyiasati hal tersebut, maka guru membuat grup kelas yang berfungsi sebagai media komunikasi antar guru dan peserta didik. ${ }^{32}$

\footnotetext{
${ }^{30}$ MTs Madani Alauddin Pao-pao “Observasi” Jln. Bontotangnga No. 36 Kelurahan Paccinongan Kecamatan Somba Opu Kabupaten Gowa (Kamis, 14 Januari 2020).

${ }^{31}$ Ahmad, Guru Mata Pelajaran Qur'an Hadis MTs Madani Alauddin Pao-pao Jln. Bontotangnga No. 36 Kelurahan Paccinongan Kecamatan Somba Opu Kabupaten Gowa (Kamis, 14 Januari 2020).

${ }^{32}$ Ahmad, Guru Mata Pelajaran Qur'an Hadis MTs Madani Alauddin Pao-pao Jln. Bontotangnga No. 36 Kelurahan Paccinongan Kecamatan Somba Opu Kabupaten Gowa (Kamis, 14 Januari 2020).
} 
Media sosial yang unik juga dapat dijadikan sarana bagi guru dalam mengawasi peserta didik, memotivasi, mengarahkan, dan memberikan peringatan kepada peserta didik. Wujud pengawasan guru kepada peserta didik dengan menggunakan media sosial dapat menggunakan beberapa fitur-fitur tersedia misalnya dengan upaya pendidik mendeteksi peserta didiknya yang eksis di media sosial atau mendeteksi peserta didik yang sering aktif hingga larut malam. Dengan demikian pendidik setidaknya mengetahui waktu-waktu yang dihabiskan peserta didiknya selama mereka berada di lingkungan tempat tinggalnya.

Wujud kedudukan pendidik sebagai motivator dengan menggunakan media sosial sebagai sarana komunikasi juga dapat dilakukan dengan intens memberikan dorongan motivasi membangkitkan semangat belajar peserta didik. Peserta didik dengan usia belasan tahun cenderung mudah dipengaruhi oleh lingkungannya, cenderung mengadopsi kebiasaan yang dianggap menarik berdasarkan apa yang mereka lihat dan dengarkan dibandingkan memotivasi diri sendiri (instrinsik) untuk lebih baik. Maka pendidik dalam hal ini dapat menjadi tokoh sentral sebagai idaman peserta didik sehingga mampu menularkan semangat positif dan kepribadian yang baik.

Melalui group media sosial, Ahmad selaku guru Qur'an Hadis MTs Madani Alauddin Paopao intens memotivasi peserta didik agar memiliki keinginan besar dan tujuan yang jelas dengan jalan semangat belajar. hal tersebut juga dijelaskan dalam proses wawancara peneliti bersama Ahmad.

Media sosial sebagai media komunikasi kami gunakan untuk memotivasi, mengarahkan, mengintruksikan, dan memberikan peringatan kepada peserta didik akan segera bergabung ke dalam kelas pembelajaran. ${ }^{33}$

Aspek lain dari peran guru adalah kedudukannya sebagai pembimbing bagi peserta didik. Proses bimbingan yang dilakukan guru dapat diekspresikan melalui peringatan atau nasehat. Adapun peringatan dan nasehat dapat dilakukan dalam group sosial media. Akhirnya, media sosial bukan hanya dimanfaatkan pendidik dalam memberikan instruksi terkait jadwal mata pelajaran tetapi juga dapat menjadi sarana komunikasi yang dapat menyentuh substansi dan tujuan dari dibuatnya group media sosial kelas, yakni untuk intensitas komunikasi antara pendidik dan peserta

b. Sebagai Intrumen Belajar

Instrumen dalam proses pembelajaran diartikan sebagai alat bantu yang dipilih dan digunakan dalam kegiatan pembelajaran mengumpulkan agar kegiatan pembelajaran tersebut, menjadi sistematis dan dipermudah olehnya. Maka segala sesuatu dalam bentuk alat atau benda yang digunakan untuk mempermudah jalannya proses pembelajaran dapat dikategorikan sebagai instrument belajar. Termasuk di sini yaitu media sosial. Selain

\footnotetext{
${ }^{33}$ Ahmad, Guru Mata Pelajaran Qur'an Hadis MTs Madani Alauddin Pao-pao Jln. Bontotangnga No. 36 Kelurahan Paccinongan Kecamatan Somba Opu Kabupaten Gowa (Kamis, 14 Januari 2020).
} 
menjadi instrumen komunikasi, media sosial juga termasuk instrument belajar apabila kedudukannya difungsikan untuk menjaring aktifitas belajar.

Salah satu ciri khas media sosial dapat dikategorikan sebagai instrument belajar adalah pemanfaatannya pada sesi mengumpulkan tugas atau proses ujian via daring serta fungsinya untuk mengakses materi pembelajaran. Sebagaimana observasi yang dilakukan oleh peneliti di MTs Madani Alauddin Paopao sebelum era pandemi covid-19, pada mata pelajaran Qur'an Hadis, media sosial difungsikan guru bagi peserta didik untuk mengumpulkan tugas dan mengakses materi belajar. hal tersebut dijelaskan oleh Ahmad selaku guru mata pelajaran Qur'an Hadis.

Media sosial telegram dan whatsApp kami gunakan dalam pembelajaran untuk memberi dan mengumpulkan tugas kepada peserta didik dan juga untuk membegikan link terkait pembelajaran. Sedangkan media sosial youtube kami gunakan sebagai media untuk mencari video berkaitan dengan materi yang sedang diajarkan, misalnya materi rezeki, kami memperlihatkan kepada peserta didik video wawancara kepada para pencari rezeki dan kemudian memberikan tugas membuat video wawancara kepada para pencari rezeki yang ada di sekitar peserta didik sesuai kreativitas peserta didik masing-masing dalam membuat pertanyaan dan membuat videonya masing-masing. ${ }^{34}$

Era covid-19 saat ini cenderung melumpuhkan sendi lembaga pendidikan, hampir setiap lembaga pendidikan mengalami kesulitan yang sama. Penggunaan media sosial yang telah dilakukan sejak sebelum era covid-19 membuat kesulitan yang dialami kiranya dapat berkurang serta teratur kendatipun kapasitas media sosial tidak akan pernah sama kualitasnya dengan proses pembelajaran tatap muka.

Proses pembelajaran yang teratur dan mudah dikontrol merupakan cita-cita kami selanjutnya, oleh karena itu kami melakukan evaluasi bulanan untuk menindaklanjuti proses pembelajaran yang dilaksanakan pada bulan tersebut. Khusus control kehadiran guru-guru dikontrol langsung oleh kepala madrasah karena kepala madrasah bergabung di setiap group kelas, sementara untuk kehadiran siswa dikontrol langsung oleh guru mata pelajaran dan wali kelas. Control kehadiran guru-guru dan peserta didik selanjutnya melakukan rekapitulasi untuk laporan evaluasi bulanan sehingga memudahkan mengambil keputusan perlakukan apa yang akan dilakukan untuk peserta didik sesuai dengan persentase kehadiran mereka. ${ }^{35}$

Hasil wawancara di atas didukung oleh data observasi yang dilakukan oleh penyusun, teknologi digital yang memuat aplikasi media sosial digunakan sebagai instrument belajar sebagaimana kelas virtual dilaksanakan dengan model tatap muka

\footnotetext{
${ }^{34}$ Ahmad, Guru Mata Pelajaran Qur'an Hadis MTs Madani Alauddin Pao-pao Jln. Bontotangnga No. 36 Kelurahan Paccinongan Kecamatan Somba Opu Kabupaten Gowa (Kamis, 14 Januari 2020).

${ }^{35}$ Herna, Waka Kurikulum MTs Madani Alauddin Pao-pao “Wawancara” Jln. Bontotangnga No. 36 Kelurahan Paccinongan Kecamatan Somba Opu Kabupaten Gowa (Kamis, 14 Januari 2020).
} 
berbasis maya sehingga pendidik dapat menyampaikan materi pelajaran Qur'an Hadis atau peserta didik dapat berdiskusi dengan saling menyaksikan satu sama lain. ${ }^{36}$

Berdasarkan penjelasan di atas, dapat dipahami bahwa media sosial dapat menjadi instrument baik dalam proses pembelajaran meliputi penilaian guru terhadap hasil belajar peserta didik serta sebagai instrument pengawasan kepala sekolah terhadap kinerja para pendidik dan segenap stakeholder lembaga pendidikan. Dengan demikian, media sosial yang multifungsi itu dapat dimaksimal fungsinya dalam proses pembelajaran, bukan hanya berkutat pada fungsinya didik.sebagai media komunikasi antara pendidik dan peserta didik.

c. Sebagai sumber Belajar

Merujuk pada pengertian sumber belajar, secara etimologi kata Sumber memiliki arti suatu sistem atau perangkat materi yang sengaja diciptakan atau disiapkan dengan maksud memungkinkan seseorang belajar. sedangkan belajar merupakan proses perubahan tingkah laku ke arah yang lebih sempurna sesuai tujuan yang telah dirumuskan sebelumnya.

Jika sumber belajar mencakupi semua daya dari luar diri peserta didik berupa manusia, alat, atau barang yang dimaksudkan untuk seseorang dapat belajar maka eksistensi media sosial dapat dikategorikan sebagai sumber belajar. Media sosial dalam konteks sumber belajar memiliki pengertian sebagai alat yang berfungsi sebagai jejaring materi pembelajaran berbasis internet.

Dewasa ini, perkembangan teknologi khususnya dalam menunjang kualitas pendidikan dimaksimalkan oleh para cendekiawan. Hal ini dibuktikan dengan maraknya bermunculan situs yang memuat materi pembelajaran, pemberdayaan teknologi digital berbasis web dan situs jurnal dari peneliti sedunia, literature yang bisa didapatkan dalam bentuk e-book, serta kompleksitas materi yang tersedia pada google sehingga peserta didik atau masiswa dapat merujuk literature tersebut sebagai sumber atau materi sebagai konsumsi otak mereka.

Selain bermanfaat bagi peserta didik, media sosial sebagai sumber belajar juga dapat memudahkan tugas dan tanggung jawab pendidik, baik sebagai media komunikasi, instrument belajar, atau sebagai ruang diskusi. Dengan media sosial, setiap pendidik mampu mengefisienkan waktu belajar, salah satu cara yang dapat ditempuh adalah dengan membagikan materi pelajaran ke dalam group media sosial untuk dipelajari peserta didik. Di sisi lain, peserta didik dapat menghemat uang dengan tidak perlu lagi membayar biaya fotocopy atau biaya print materi pelajaran, makalah, dan tugas-tugas lainnya.

Sangat banyak aplikasi media sosial yang dapat dikategorikan sebagai sumber balajar, contohnya, youtube, facebook, whatsapp, situs jurnal atau web seperti schoolar,

\footnotetext{
${ }^{36}$ MTs Madani Alauddin Pao-pao “Observasi” Jln. Bontotangnga No. 36 Kelurahan Paccinongan Kecamatan Somba Opu Kabupaten Gowa (Kamis, 14 Januari 2020).
} 
dan banyak lagi aplikasi media sosial lainnya. Dengan memfungsikan media sosial sebagai sarana menemukan materi belajar atau membagikan link materi atau video pendidikan maka media sosial setidaknya memiliki kedudukan serupa dengan sumber belajar yang umum dikenal seperti buku, jurnal, guru, dan sebagainya.

Sebagaimana pembelajaran Qur'an Hadis di MTs Madani Alauddin Paopao Kabupaten Gowa, pada prosesnya, pemberdayaan aplikasi media sosial merupakan pilihan utama sebagai penunjang kreatifitas pendidik dengan mempertimbangkan efisiensi waktu. Hal tersebut disebabkan karena durasi belajar via daring berkurang dibandingkan proses pembelajaran tatap muka, dimana sebelumnya durasi belajar perjam pada pembelajaran tatap muka sebanyak 45 menit, dikurangi menjadi 30 menit/jam.

Kembali pada media sosial sebagai sumber belajar, Ahmad selaku guru Qur'an Hadis MTs Madani Alauddin Paopao menjelaskan.

Proses pembelajaran via daring juga dilakukan dengan memanfaatkan aplikasi youtube sebagai sumber belajar. biasanya saya mengirim link youtube yang sesuai dengan pembahasan materi. Peserta didik ditugaskan untuk menonton full video yang dikirim selanjutnya memberikan ulasan berdasarkan pemahaman mereka. Tetapi seringkali juga video yang dikirim hanya diskip sesuai instruksi tugas oleh sebagaian peserta didik. Misalnya, guru memerintahkan peserta didik agar menononton, menyimak video, dan menemukan satu pertanyaan dari video tersebut namun ada juga peserta didik yang hanya sekedar mencari bagian yang menurutnya akan dipertanyakan tanpa menonton full videonya. Artinya, ada sebagian kecil peserta didik yang aktif bertanya dan memang mengikuti arahan guru sepenuhnya, tetapi sangat banyak peserta didik yang abai dengan arahan guru. Peserta didik tipe ini biasanya nanti kalang kabut mengerjakan tugas karena malas dan kurang aktif mengikuti proses pembelajaran. ${ }^{37}$

Sedikit banyaknya tantangan dalam proses pembelajaran di era pandemi covid-19 juga dialami oleh guru mata pelajaran Qur'an Hadis di MTs Madani Alauddin Paopao Kabupaten Gowa. Sebagaimana dipahami bahwa beberapa aspek materi mata pelajaran Qur'an Hadis menekankan praktik baca tulis al-Quran.

\section{B. Motivasi Belajar Peserta Didik Kelas VIII pada Mata Pelajaran Qur'an Hadis}

\section{Menggunakan Media Sosial di MTs Madani Alauddin Paopao Kabupaten Gowa}

Berbicara tentang motivasi belajar peserta didik secara umum tidak dapat dipastikan keseluruhan dari mereka memiliki tingkatan motivasi dan minat yang sama. Untuk mengidentifikasi persoalan ini dapat diamati pada kesungguhan serta upaya peserta didik selama proses pembelajaran tengah berlangsung. Demikian pada point bab ini, motivasi belajar peserta didik pada mata pelajaran Qur'an Hadis dengan menggunakan media sosial di kelas VIII Mts. Madani Alauddin Pao-pao Kabupaten Gowa diklasifikasikan menjadi tiga macam meliputi; pertama, motivasi peserta didik dalam proses pembelajaran Qur'an Hadis yang sub-pointnya terbagi dua kategori yakni ketegori

\footnotetext{
${ }^{37}$ Ahmad, Guru Mata Pelajaran Qur'an Hadis MTs Madani Alauddin Pao-pao Jln. Bontotangnga No. 36 Kelurahan Paccinongan Kecamatan Somba Opu Kabupaten Gowa (Kamis, 14 Januari 2020).
} 
yang aktif dan kategori yang kurang aktif. Kedua, faktor-faktor yang mempengaruhi motivasi belajar peserta didik meliputi; faktor keluarga, faktor kebiasaan diri, faktor teman sepergaulan, dan intensitas dorongan dari lembaga pendidikan.

\section{Motivasi Peserta Didik dalam Pembelajaran Qur'an Hadis dengan}

\section{Menggunakan Media Sosial}

Klasifikasi motivasi peserta didik dalam proses pembelajaran Qur'an Hadis dengan menggunakan media sosial whatsApp, telegram dan youtube adalah sebagai berikut:

a. Motivasi Belajar Peserta Didik dalam Pembelajaran Qur'an Hadis dengan

Menggunakan Media Sosial WhatsApp dan Telegram.

Peserta didik di MTs Madani Alauddin Paopao Kabupaten Gowa secara umum aktif mengikuti proses pembelajaran Qur'an Hadis, namun demikian tidak semua peserta didik memiliki motivasi yang tinggi dalam keterlibatan belajar. hal ini ditandai ketika proses pembelajaran berlangsung, adakalanya peserta didik hanya sebatas hadir mengikuti proses pembelajaran, demikian pula sebagian dari peserta didik aktif berkonsultasi dengan guru mata pelajaran Qur'an Hadis melalui media sosial. Data tersebut diperoleh dari hasil observasi penyusun melalui group whatsapp kelas VIII MTs Madani Alauddin Paopao. $^{38}$

Motivasi belajar sarat dengan keingintahuan peserta didik dalam wujud ekspresi dan tindakan. Peserta didik yang memiliki motivasi besar maka ia cenderung mengekspresikan motivasinya dengan ragam cara, misalnya dengan banyak bertanya, banyak mencari informasi, intens melakukan diskusi dalam ruang belajar, dan membangun komunikasi yang baik dengan pendidiknya. Dengan demikian motivasi belajar atau secara sederhana dapat dikatakan kesadaran belajar sebagai kepekahan intelektual adalah sangat akrab dengan sumber belajar.

Sebagaimana hasil wawancara dengan Ahmad selaku guru mata pelajaran Qur'an Hadis, ia menjelaskan bahwa:

Peserta didik yang benar-benar aktif termotivasi dan memanfaatkan media sosial sebagai penunjang pembelajaran jika persentasekan hanya sekitar $40 \%$ sampai dengan $60 \%$. Sisanya cenderung abai, mungkin disebabkan godaan-godaan aktivitas media sosial yang trending dan kekinian sehingga mereka kurang focus terhadap aspek edukasi sosial media. ${ }^{39}$

Menggunakan media sosial sebagai alat pendukung proses pembelajaran kendatipun karena keadaan memaksakan demikian namun pada prosesnya hanya ada beberapa peserta didik yang mampu eksis terlibat dalam proses pembelajaran. Selain itu, tolak ukur motivasi peserta didik tidak lantas dianggap karena faktor media sosial semata,

${ }^{38}$ MTs Madani Alauddin Pao-pao “Observasi” Jln. Bontotangnga No. 36 Kelurahan Paccinongan Kecamatan Somba Opu Kabupaten Gowa (Kamis, 14 Januari 2020).

\footnotetext{
${ }^{39}$ Ahmad, Guru Mata Pelajaran Qur'an Hadis MTs Madani Alauddin Pao-pao Jln. Bontotangnga No. 36 Kelurahan Paccinongan Kecamatan Somba Opu Kabupaten Gowa (Kamis, 14 Januari 2020).
} 
tetapi kebanyakan peserta didik aktif termotivasi belajar karena menyukai mata pelajaran tersebut. Dengan demikian, motivasi belajar bukan semata karena aspek kesungguhan beradaptasi dari yang sebelumnya tidak tahu menjadi tahu, akan tetapi hal lain yang menyebabkannya termotivasi karena memfavoritkan mata pelajaran tertentu, karena itu peserta didik eksis mengikuti sekaligus aktif dalam proses belajar mengajar.

Selanjutnya, Ahmad menambahkan motivasi belajar via daring atau dikusi dalam group whatsapp adalah sesuatu yang relative, artinya untuk mengukur itu hendaknya dengan memperhatikan banyak hal, misalnya keterampilan mengoperasikan android atau karena aspek usia. Sebagaimana dipaparkan.

Proses pembelajaran dengan melibatkan teknologi digital baik itu via zoom atau dalam group whatsapp dan telegram tidak efisien untuk kategori peserta didik sekolah menengah pertama. Ini dibuktikan ada sebagian kecil peserta didik yang aktif bertanya dan memang mengikuti arahan guru sepenuhnya, tetapi sangat banyak peserta didik yang abai dengan arahan guru. Peserta didik tipe ini biasanya nanti kalang kabut mengerjakan tugas karena malas dan kurang aktif mengikuti proses pembelajaran. ${ }^{40}$

Berdasarkan penjelasan di atas, dapat dipahami bahwa kriteria motivasi belajar peserta didik khususnya pada mata pelajaran Qur'an Hadis hendaknya diukur berdasarkan keaktifan mereka mengikuti dan terlibat penuh dalam proses pembelajaran. Di samping itu, peserta didik dengan kapasitasnya yang masih belia cenderung berpotensi mengadopsi nilai-nilai yang diperoleh dari lingkungan keluarga dan teman sepergaulannya. Pengaruh dari keluarga dan teman sepergaulan dapat menjadi sarana mendeteksi tingkat motivasi peserta didik.

b. Motivasi Belajar Peserta Didik dalam Pembelajaran Qur'an hadis dengan

Menggunakan Media Sosial Youtube.

Peserta didik untuk kategori sekolah menengah pertama, di usianya masih dominan masa bermain daripada belajar. Kendatipun demikian peserta didik memiliki status sebagai pelajar, dengan identitas itu setidaknya menjadi dasar bagi mereka untuk menyisihkan waktu belajar dalam sehari. Di samping itu, keberadaan orang tua peserta didik dapat menjadi pertimbangan bagi lembaga pendidikan agar intens mengawasi peserta didik khususnya ketika mereka berada di lingkungan keluarga.

Keragaman motivasi peserta didik bukanlah merupakan sesuatu yang baru dalam sebuah lembaga pendidikan, hampir setiap lembaga pendidikan memiliki pelajar yang semangat belajarnya berbeda-beda. Sebagaimana di MTs Madani Alauddin Paopao Kabupaten Gowa, sebagian peserta didik kurang termotivasi dengan pembelajaran Qur'an Hadis yang diselenggarakan dengan menggunakan teknologi digital, via zoom atau media sosial whatsApp dan telegram.

\footnotetext{
${ }^{40}$ Ahmad, Guru Mata Pelajaran Qur'an Hadis MTs Madani Alauddin Pao-pao Jln. Bontotangnga No. 36 Kelurahan Paccinongan Kecamatan Somba Opu Kabupaten Gowa (Kamis, 14 Januari 2020).
} 
Ahmad, selaku guru Qur'an Hadis di MTs Madani Alauddin Paopao Kabupaten Gowa menyuasati hal demikian dengan memanfaatkan media sosial Youtube untuk merangsang motivasi peserta didik untuk kembali aktif dalam pembelajaran.

Peserta didik ditugaskan untuk menonton full video yang dikirim selanjutnya memberikan ulasan berdasarkan pemahaman mereka, lalu ditugaskan kembali untuk membuat video serupa dengan tayangan yang ditontonnya. Hal ini mendapat respon yang cukup baik dari peserta didik. ${ }^{41}$

Hasil wawancara di atas didukung oleh data penelitian melalui observasi penyusun pada group whatsapp kelas VIII MTs Madani Alauddin Paopao Kabupaten Gowa, pada observasi tersebut stimulus yang diberikan pendidik mendapat respon baik dari peserta didik, tergambar dari keuletan dan semangat mereka menanggapi video youtube yang ditontonnya dan membuat video serupa dan mengumpulkannya videonya kepada guru. 42 Dengan demikian dapat dipahami bahwa pelajaran via daring atau media sosial dalam pembelajaran Qur'an Hadis secara dominan membangkitkan semangat dan motivasi peserta didik.

\section{Faktor yang Mempengaruhi motivasi Belajar Peserta Didik pada Mata}

\section{Pembelajaran Qur'an Hadis Menggunakan Media Sosial}

Pada bagian ini, faktor-faktor motivasi peserta didik dalam pembelajaran Qur'an Hadis melalui media sosial diklasifikasikan menjadi empat faktor meliputi; faktor keluarga, faktor kebiasaan diri, faktor teman sepergaulan, dan intensitas dorongan dari lembaga pendidikan. Adapun penjelasannya sebagai berikut:

a. Kerjasama Antara Pihak Madrasah dengan Orangtua Peserta Didik

Penanaman kebiasaan belajar peserta didik di mulai dari keluarga. Keberadaan keluarga dalam hal ini orangtua peserta didik mampu menjadi dorongan bagi peserta didik agar termotivasi. Demikian pentingnya peran keluarga bagi semangat belajar peserta didik karena sebagian besar waktu mereka dihabiskan bersama orangtua dan sanak saudara di lingkungan tempat tinggal peserta didik.

Memperhatikan potensi keluarga bagi pembinaan inteletual peserta didik, seyogyanya lembaga pendidikan menjadikannya mitra dalam membina generasi yang cerdas dan berkarakter. Kerjasama antara lembaga pendidikan dan orangtua peserta didik dapat dilakukan dengan aneka cara, secara umum dengan membangun hubungan yang baik dan intens melakukan pertemuan rutin dengan membahas persoalan yang dialami peserta didik.

\footnotetext{
${ }^{41}$ Ahmad, Guru Mata Pelajaran Qur'an Hadis MTs Madani Alauddin Pao-pao Jln. Bontotangnga No. 36 Kelurahan Paccinongan Kecamatan Somba Opu Kabupaten Gowa (Kamis, 14 Januari 2020).

${ }^{42}$ MTs Madani Alauddin Pao-pao “Observasi” Jln. Bontotangnga No. 36 Kelurahan Paccinongan Kecamatan Somba Opu Kabupaten Gowa (Kamis, 14 Januari 2020).
} 
Hal tersebut dijelaskan oleh Herna, Kasi Kurikulum MTs Madani Alauddin Paopao Kabupaten gowa.

Era pandemi ini dapat dijadikan peringatan bagi para orangtua agar bisa menyaksikan langsung bagaimana mendidik anak-anak mereka ketika gurugurunya berada atau sementara belajar di sekolah sebagaimana dipahami fenomena ini juga turur dirasakan langsung oleh para orangtua peserta didik. Peluang lebih dekat antara anak dan orangtua, yang mana sekarang ini mungkin saja hubungan antara anak dan orangtua disebabkan orangtua sibuk dengan pekerjaannya sementara anak-anak harus berangkat ke sekolah. Sekarang, kondisi Covid-19 berkata lain bahwa antara anak dan orangtua akan semakin intens bersama sehingga kedekatan antara peserta didik dan orangtuanya akan terbina dan terjalin dengan baik. $^{43}$

Mengingat pentingnya membangun kerjasama antara pihak lembaga pendidikan dengan orangtua peserta didik, stakeholder MTs Madani Alauddin Paopao membuat group untuk para orangtua guna bersama-sama memotivasi peserta didik ketika mereka berada di lingkungan keluarga. Sebagaimana pula dijelaskan oleh Abd. Rajab selaku kepala madrasah MTs Madani Alauddin Paopao.

Pihak sekolah tidak berhenti pada inisitif menyediakan sarana prsarana, Alhamdulillah kita juga melakukan evaluasi laporan bulanan untuk mendeteksi kelemahan yang ada selanjutnya dibenahi secara bersama-sama oleh segenap elemen sekolah. Kami dari pihak sekolah intens membangun komunikasi dengan orangtua peserta didik dengan membuat group whatsapp orangtua peserta didik agar para orangtua lebih ketat mengawasi anak-anak mereka sehingga kerjasama antara pihak sekolah dengan keluarga peserta didik dapat terbangun dengan baik. Kerjasama ini sangat membantu peserta didik sebagai generasi yang memiliki hak pelayanan belajar. ${ }^{44}$

Keadaan sekarang dimana setiap masyarakat diperintahkan menjaga jarak dan belajar dari rumah kiranya menjadi peluang bagi para orangtua peserta didik agar lebih dekat dengan anak-anak mereka sekaligus memahami situasi belajar dan mengajar dengan demikian para orangtua setidaknya dapat menyisihkan waktu untuk mengawasi atau bahkan mengajar peserta didik sebagaimana yang mereka amati ketika peserta didik mengikuti proses pembelajaran dari rumah dengan menggunakan sarana virtual.

b. Control Lembaga Pendidikan

Ciri khas generasi mellenial sekarang ini ditandai dengan keakraban mereka dengan teknologi digital. Berbeda dengan generasi 90-an, dimana untuk segala hal menyangkut informasi pendidikan sangat sulit diperoleh secara instan. Sementara itu, generasi abad 20, hampir setiap mereka memiliki gadget sehingga memudahkan mereka mengoogling artikel dan materi pelajaran.

\footnotetext{
${ }^{43}$ Herna, Waka Kurikulum MTs Madani Alauddin Pao-pao “Wawancara” Jln. Bontotangnga No. 36 Kelurahan Paccinongan Kecamatan Somba Opu Kabupaten Gowa (Kamis, 14 Januari 2020).

${ }^{44}$ Abd. Rajab, Kepala Madrasah “Wawancara” MTs. Madani Alauddin Pao-pao Jln. Bontotangnga No. 36 Kelurahan Paccinongan Kecamatan Somba Opu Kabupaten Gowa (Kamis, 14 Januari 2020).
} 
Melalui kebiasaan mengoperasika gadget atau android, hal tersebut menjadikan peserta didik percaya diri mengikuti proses pembelajaran via zoom/classroom. Karena kenyataan demikian, generasi saat ini membutuhkan pengawasan yang ketat dari berbagai pihak, tidak terkecuali dari lembaga pendidikan sebagaimana dipahami bahwa gadget di samping membawa pengaruh positif juga terdapat sisi negative yang dapat mempengaruhi peserta didik.

Ketika media sosial diarahkan pada pembangunan sumber daya manusia yang berkualitas maka hal itu bisa saja terjadi dengan jalan memaksimalkan fungsi-fungsinya untuk mendukung tradisi intelektual. Salah satu cara yang dapat diterapkan yakni dengan meningkatkan intensitas motivasi pihak lembaga pendidikan terhadap peserta didik. Dengan media sosial, guru dapat mengawasi peserta didik sekaligus ia memiliki peluang memotivasi mereka bahkan di luar jam sekolah. Kenyataan yang terjadi bahwa guru Qur'an Hadis intens memotivasi peserta didik dalam group whatsapp kelas. ${ }^{45}$ Adapun persoalan respon peserta didik merupakan sesuatu yang perlu dibina tahapan demi tahapan.

Pihak MTs Madani menekankan pengawasan yang ketat baik itu pada pengawasan kepada peserta didik ataupun pengawasan terhadap para guru mata pelajaran. Pada observasi yang dilakukan penyusun, ditemukan pada group whatsapp setiap kelas dimana secara sederhana dapat dikatakan bahwa media sosial digunakan oleh guru untuk mengawasi peserta didik, serta digunakan pula oleh kepala sekolah untuk mengawasi guru mata pelajaran. Hal tersebut karena kepala sekolah bergabung pada setiap group peserta didik dan guru. ${ }^{46}$

Kepekaan dan kesadaran merasa diawasi merupakan salah satu point penting bagi setiap elemen guru dan peserta didik agar problematika pendidikan dapat diidentifikasi melalui pengamatan berkelanjutan. Lebih lanjut, Herna selaku kepala seksi kurikulum menjelaskan.

Khusus control kehadiran guru-guru dikontrol langsung oleh kepala madrasah karena kepala madrasah bergabung di setiap group kelas, sementara untuk kehadiran siswa dikontrol langsung oleh guru mata pelajaran dan wali kelas. Control kehadiran guru-guru dan peserta didik selanjutnya direkap untuk laporan evaluasi bulanan sehingga memudahkan mengambil keputusan perlakukan apa yang akan dilakukan untuk peserta didik sesuai dengan persentase kehadiran mereka. ${ }^{47}$

Tidak dapat dipungkiri bahwa kemandirian dan kesadaran tanggung jawab sebagai pendidik merupakan faktor penting terselenggaranya pendidikan dengan baik kendatipun

\footnotetext{
${ }^{45}$ MTs Madani Alauddin Pao-pao “Observasi” Jln. Bontotangnga No. 36 Kelurahan Paccinongan Kecamatan Somba Opu Kabupaten Gowa (Kamis, 14 Januari 2020).

${ }^{46}$ MTs Madani Alauddin Pao-pao “Observasi” Jln. Bontotangnga No. 36 Kelurahan Paccinongan Kecamatan Somba Opu Kabupaten Gowa (Kamis, 14 Januari 2020).

${ }^{47}$ Herna, Waka Kurikulum MTs Madani Alauddin Pao-pao “Wawancara” Jln. Bontotangnga No. 36 Kelurahan Paccinongan Kecamatan Somba Opu Kabupaten Gowa (Kamis, 14 Januari 2020).
} 
tanpa perasaan was-was dan tekanan karena merasa diawasi. Namun demikian penting pula suatu pengawasan dilakukan karena setiap elemen lembaga pendidikan memiliki peran, tugas, dan tanggung jawab yang berbeda. Adapun kepala madrasah dalam hal ini memiliki tanggung jawab mengawasi kinerja para pendidik khususnya di Mts. Madani Alauddin Pao-pao Kabupaten Gowa.

\section{SIMPULAN}

Mengacu pada hasil penelitian, maka secara sederhana benang merah penelitian ini dapat diuraikan berdasarkan point penting sesuai focus penelitian, yaitu sebagai berikut:

1. Peranan media sosial bagi peserta didik kelas VIII mata pelajaran qur'an hadis MTs Madani Alauddin Pao-pao Kabupaten Gowa yaitu dengan mendayagunakan media sosial sebagai instrumen komunikasi, instrumen belajar, ruang belajar, dan sumber belajar.

2. Perspektif belajar peserta didik diklasifikasikan beberapa point pembahasan meliputi; motivasi peserta didik dengan menggunakan media sosial whatsApp dan telegram dalam pembelajaran Qur'an Hadis, motivasi peserta didik dengan menggunakan media sosial youtube dalam pembelajaran Qur'an Hadis serta faktorfaktor yang mempengaruhi motivasi belajar peserta didik pada mata pelajaran qur'an hadis via media sosial meliputi kerjasama dengan orangtua peserta didik serta intensitas controlling pengawasan lembaga pendidikan.

3. Peranan media sosial bagi peserta didik kelas VIII pada mata pelajaran Qur'an Hadis MTs Madani Alauddin Paopao Kabupaten Gowa khususnya dalam penggunaan media sosial whatsApp, telegram dan youtube yakni: Peserta didik mampu belajar mandiri, terbentuknya kerjasama antar guru dengan orangtua peserta didik, meningkatkan kreatifitas peserta didik, mampu menjadi instrumen belajar bagi peserta didik dan membentuk kerjasama yang lebih baik. Adapun yang menjadi kendala dalam pembelajaran menggunakan media sosial adalah bertumpu pada kekuatan signal.

\section{DAFTAR PUSTAKA}

Ahmad, A. Kadir. Dasar-dasar MetodologiPenelitianKualitatif. Makassar: Indobis Media Centre, 2003.

Al-Sayuti, Lubab An-Nuqul fi Asbab An-Nuzul. Kairo: Darul Inan, 2001. 
Andrizal, A., dkk. Pengembangan Mediapembelajaran Interaktif Padasistem E-Learning Universitasnegeri Padang.Invotek: Jurnal Inovasivokasional dan Teknologi, 17. 2. 2017.

Arifin, M. Ilmu Pendidikan Islậm Suatu Tinjauan Teoretis dan Praktis Berdasarkan Pendekatan Interdisipliner. Cet. V; Jakarta: BumiAksara, 2000.

Arikunto, Suharsimi. Prosedur Penelitian: Suatu Pendekatan Praktik. Jakarta: RinekaCipta, 2006.

Aunurrahman. Belajar dan Pembelajaran. Bandung: Alfabeta. 2010.

Azhar Arsyad. Media Pembelajaran. Jakarta: Rajawali Pers. 2011.

Darsono. Belajar dan Pembelajaran. Semarang: Semarang Press. 2000.

Dimyati dkk. Belajar dan Pembelajaran. Jakarta: Rineka Cipta, 2009.

Djamarah, Syaiful Bahri. Psikologi Belajar. Jakarta: Rineka Cipta, 2011.

Hadi, Sutrisno. Statistik 1. Yogyakarta: Penerbit Andi Offset, 1993.

Hosnan, M. Pendekatan Saintifik dan Kontekstual dalam Pembelaajran Abad 21. Bogor: Ghalia Indonesia. 2014.

Junaid, Ilham. "Analisis data kualitatif dalam penelitian pariwisata." Jurnal Kepariwisataan 10.1. 2016.

Kaplan, Andreas M., dkk "Users of the World, Unite! The challenges and Opportunities of Social Media", Business Horizon, 2010.

Kompri. 2016. Motivasi Pembelajaran Perspektif Guru dan Siswa. Bandung: PT Rosda Karya.

Lesmana, Gusti Ngurah Aditya. "Analisis Pengaruh Media Sosial Twitter terhadap Pembentukan Brand Attacment.” Tesis. Jakarta: Universitas Indonesia. 2012.

Lestari, Fitria. "Pengaruh Jiwa Kewirausahaan dan Kreativitas terhadap Keberhasilan Usaha pada Sentra Industri Rjutan Binong Jati Bandung." Available at elib.unikom.ac. id 8. 2013.

Manab, Abdul. "Menggagas Penelitian Pendidikan: Pendekatan Studi Kasus." 2016.

Moh. Zamili, "Menghindar dari Bias: Praktik Triangulasi dan Kesahihan Riset Kualitatif." Lisanal- Hal: Jurnal Pengembangan Pemikiran dan Kebudayaan 9.2. 2015.

Moleong, Lexy J. Metodologi Penelitian Kualitatif. Cet. XIII; Bandung: Remaja Rosdakarya, 2001.

Nasution, S. Metode Research: Penelitian Ilmiah. Cet. XII; Jakarta: Bumi Aksara, 2011. 
Nawawi, Hadari dkk. Instrumen Penelitian Bidang Sosial. Cet. II; Yogyakarta: Gajah Mada University Press, 1995.

Padmowihardjo, Soedijanto. Psikologi Belajar Mengajar. Tangerang Selatan: Universitas Terbuka, 2016.

Poore, Megan. Studying and Researching with Social Media. Los Angeles: Sage Study Skills, 2014.

Purnama, Hadi. Media Sosial Di Era Pemasaran 3.0 Corporate And Marketingcommunication. Jakarta: Pusat Studi Komunikasi Dan Bisnis Program Pascasarjana Universitas Mercu Buana, 2010. 